\title{
Delivery characteristics and patients' handling of two single-dose dry-powder inhalers used in COPD
}

This article was published in the following Dove Press journal:

International Journal of COPD

22 June 2011

Number of times this article has been viewed

\section{Kenneth R Chapman' \\ Charles M Fogarty ${ }^{2}$ \\ Clare Peckitt ${ }^{3}$ \\ Cheryl Lassen ${ }^{3}$ \\ Dalal Jadayel ${ }^{3}$ \\ Juergen Dederichs ${ }^{4}$ \\ Mukul Dalvi ${ }^{4}$ \\ Benjamin Kramer ${ }^{5}$ \\ On behalf of the INDEED \\ (indacaterol: handling and preference evaluation of the Breezhaler device in COPD) study investigators}

'University of Toronto, Toronto, Canada; ${ }^{2}$ Spartanburg Medical Research, Spartanburg, SC, United States; ${ }^{3}$ Novartis Horsham Research Centre, Horsham, West Sussex, UK; ${ }^{4}$ Novartis Pharma AG, Basel, Switzerland; ${ }^{5}$ Novartis Pharmaceuticals, East Hanover, NJ, USA
Correspondence: Kenneth R Chapman Asthma and Airway Centre, University Health Network, Toronto Western Hospital, Rm. 7-45I East Wing, 399 Bathurst Street,Toronto,

Ontario, Canada

Tel + I 4l66035499

Fax + I 4I66033456

Email kchapman@ca.inter.net
Abstract: For optimal efficacy, an inhaler should deliver doses consistently and be easy for patients to use with minimal instruction. The delivery characteristics, patients' correct use, and preference of two single-dose dry powder inhalers (Breezhaler and HandiHaler) were evaluated in two complementary studies. The first study examined aerodynamic particle size distribution, using inhalation profiles of seven patients with moderate to very severe chronic obstructive pulmonary disease (COPD). The second was an open-label, two-period, 7-day crossover study, evaluating use of the inhalers with placebo capsules by 82 patients with mild to severe COPD. Patients' correct use of the inhalers was assessed after reading written instructions on Day 1, and after training and 7 days of daily use. Patients' preference was assessed after completion of both study periods. Patient inhalation profiles showed average peak inspiratory flows of $72 \mathrm{~L} /$ minute through Breezhaler and $36 \mathrm{~L} /$ minute through HandiHaler. For Breezhaler and HandiHaler, fine particle fractions were $27 \%$ and $10 \%$, respectively. In the second study, correct use of Breezhaler and HandiHaler was achieved by $>77 \%$ of patients for any step after 7 days; $61 \%$ of patients showed an overall preference for Breezhaler and $31 \%$ for HandiHaler $(P=0.01)$.

Breezhaler is a low-resistance inhaler suitable for use by patients with a range of disease severities. Most patients used both inhalers correctly after 7 days, but more patients showed an overall preference for the Breezhaler compared with the HandiHaler. These are important factors for optimum dose delivery and successful COPD management.

Keywords: Breezhaler, HandiHaler, COPD, use, preference, dose delivery

\section{Introduction}

A patient's ability to use an inhaler correctly and their preference for the inhaler are both important factors in selecting an appropriate treatment for chronic obstructive pulmonary disease (COPD). ${ }^{1}$ Incorrect handling of inhalation devices is common in COPD and is influenced not only by patient-related factors (eg, physical ability) but also by the type of inhaler prescribed and the adequacy of patient education. ${ }^{2-4}$ Poor handling and inhalation technique may result in suboptimal drug delivery to the lower airway, ${ }^{2,5-7}$ which can ultimately reduce compliance and prevent successful disease management. 8,9

The aerodynamic size of drug particles generated by inhalers is critical in determining the distribution and deposition of drug within the lung, with the fine particle fraction or FPF (defined as fraction of particles less than $5 \mu \mathrm{m}$ in diameter) generally considered optimum to deposit in the bronchi and alveoli. Thus, dose delivery from a dry powder inhaler (DPI) depends not only on correct handling and inhalation, but also on the inhaler's internal resistance and its ability to generate sufficient fine 
particles to ensure drug deposition in the lower airway. ${ }^{10}$ High-resistance devices require greater effort by the patient to achieve inspiratory flows adequate to ensure FPF dose delivery, ${ }^{11}$ and some patients with significant pulmonary disease cannot generate these flows. ${ }^{12,13}$

Inhaled long-acting bronchodilators are used for the treatment of patients with moderate and more severe COPD, ${ }^{14}$ with two agents available for once-daily administration. Indacaterol is a novel, inhaled, once-daily, ultra-long-acting $\beta_{2}$-agonist ${ }^{15}$ delivered by a single-dose DPI known as the Breezhaler ${ }^{\circledR}$ in some countries, and approved in more than 40 countries for maintenance treatment in COPD. The other once-daily inhaled bronchodilator is the anticholinergic, tiotropium, delivered by a single-dose DPI called the HandiHaler ${ }^{\circledR}$.

This paper presents the results of two complementary studies. The first was an in vitro study evaluating the dose delivery characteristics from the single-dose DPIs used with indacaterol (Onbrez ${ }^{\circledR}$ Breezhaler $^{\circledR}$ [Novartis Pharma AG, Basel, Switzerland]) and tiotropium (Spiriva ${ }^{\circledR}$ HandiHaler $^{\circledR}$ [Boehringer-Ingelheim, Ingelheim, Germany]). The two inhalers were compared under a range of simulated inspiratory flow conditions modeled from data obtained from COPD patients with disease severities ranging from mild to severe. The second study assessed patients' correct use and preference for Breezhaler and HandiHaler using placebo capsules.

\section{Methods}

\section{In-vitro dose delivery study}

The aerodynamic particle distribution of indacaterol $150 \mu \mathrm{g}$ via Breezhaler and tiotropium $18 \mu \mathrm{g}$ via HandiHaler was measured using a standard Next Generation Impactor (NGI, MSP Corporation, Shore view, MN) with pre-separator and induction port coupled to a flow-volume simulator (Figure 1). Neutral sum air flow at experimental rest was required to facilitate particle generation during the simulated breathing maneuvers and was achieved by an auxiliary air supply at the mixing inlet and vacuum pump at the impactor outlet at $100 \mathrm{~L} /$ minute and $60 \mathrm{~L} /$ minute, respectively, for the Breezhaler and HandiHaler. The patients' breathing patterns were reproduced at the mouthpiece of the DPIs by modulating the air flow using the computer-controlled flow-volume simulator. Three replicate measurements were obtained for each simulated patient flow profile, using a new DPI for each determination. The simulated flow profiles closely resembled the original patient flow profiles with $<3 \%$ mean relative difference over all flow values.

Seven patient inhalation flow profiles were chosen from a group of profiles obtained from 28 patients. The profiles were selected to cover disease severities from moderate to severe and a representative range of patient age, gender and airflow obstruction. In addition, the technical specification of the experimental apparatus determined that the selected profiles were within maximum peak inspiratory flows of

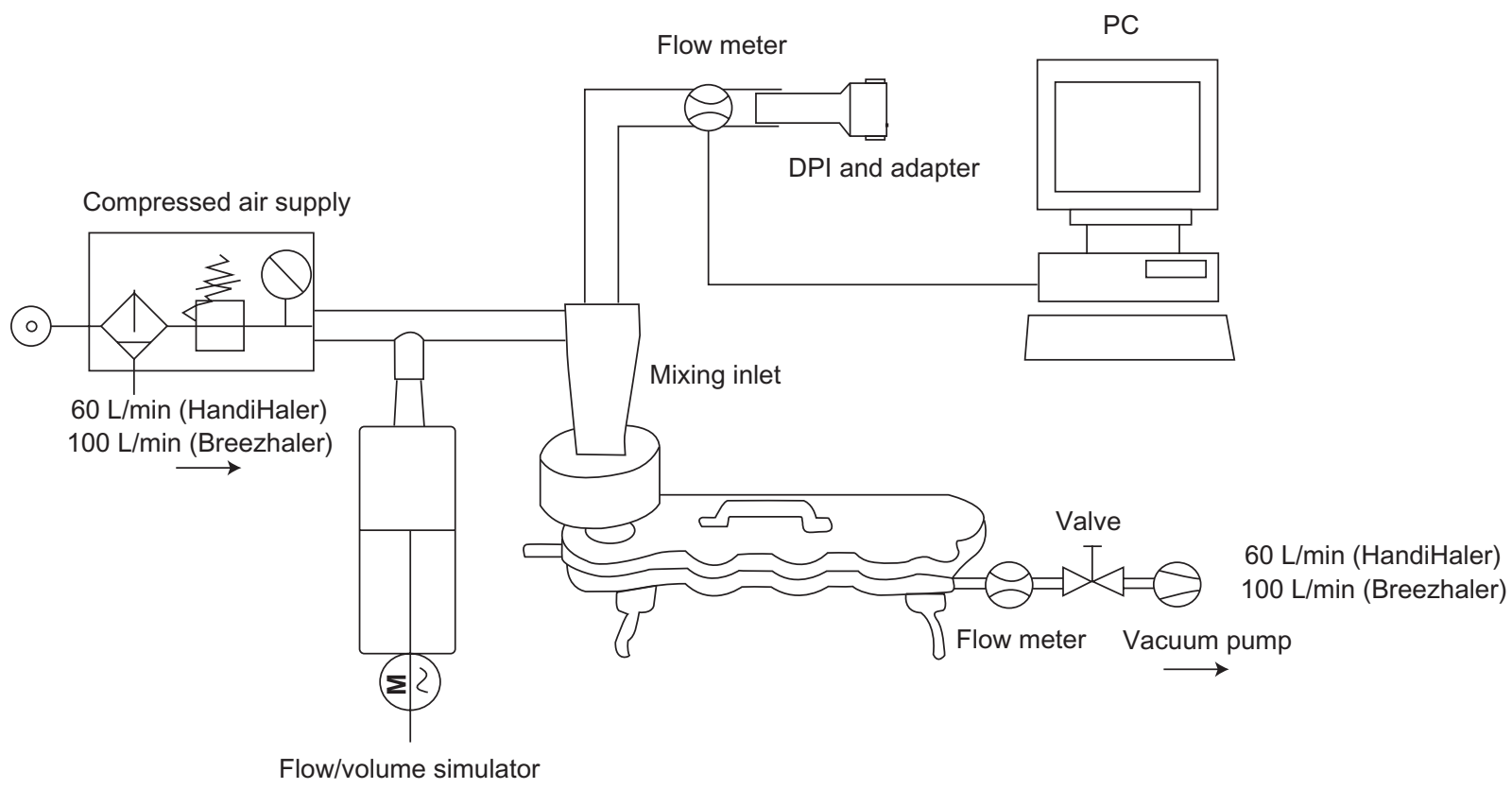

Figure I Experimental set-up with flow/volume simulator.

Abbreviation: DPI, dry powder inhaler. 
$100 \mathrm{~L} /$ minute. This is the maximum possible that can be achieved through the NGI in order to measure aerodynamic particle size distribution when simulating recorded patient flow patterns.

Quantification of indacaterol and tiotropium depositions from the NGI analysis was performed using high-performance liquid chromatography on two samples from each NGI component. Fine particle dose and particle size (defined by median mass aerodynamic diameter) were measured and geometric standard deviation (GSD) determined. GSD is a measure of the variability of the particle diameters within the aerosol. An aerosol with a GSD of 1 is described as monodisperse (uniform diameter distribution); an aerosol with a GSD $>1.2$ is heterodisperse (heterogeneous particle distribution). ${ }^{16}$

Based on the results of the particle size analysis, the theoretical respiratory tract deposition (extrathoracic, representing the portion 'lost' through oropharyngeal deposition, versus intrathoracic, delivered to the lower airways) for each of the patient breathing profiles was estimated using a semiempirical deposition model for healthy lungs. ${ }^{17}$

The in vitro dose delivery study was carried out at Inamed Research $\mathrm{GmbH}$ and Co KG, Gauting, Germany.

\section{Assessment of patients' correct use of, and preference for, inhalers}

This was a multicenter study conducted in Canada and the USA. The protocol was approved by the appropriate institutional review board for each participating center (Institutional Review Board Services, Aurora, Ontario L4G 0A5, Canada; Quorum Review, Inc., Seattle WA 98101, USA; Dean Institutional Review Board, Middleton WI 53562, USA).

\section{Patients}

The study enrolled co-operative male and female patients aged $\geq 40$ years with a clinical diagnosis of mild to severe $\mathrm{COPD}^{18}$ (post-bronchodilator forced expiratory volume in 1 second $\left[\mathrm{FEV}_{1}\right]>30 \%$ predicted; $\mathrm{FEV}_{1} /$ forced vital capacity $<70 \%$ ) and smoking history $\geq 10$ pack-years. The patients required use of inhaled medication in the management of their COPD, but had no previous experience of either study inhaler (or the similar DPI Foradil ${ }^{\circledR}$ Aerolizer $^{\circledR}$ [Novartis Pharma AG, Basel, Switzerland] used to administer the twice-daily bronchodilator formoterol). Patients gave their written informed consent before any assessment was performed.

\section{Study design}

This was an open-label, multicenter, two-period, 7-day crossover study (Figure 2). Patients used Breezhaler or HandiHaler with placebo capsules once daily each for 7 days in random sequence, in addition to their usual treatment. On Day 1, patients were asked to read written instructions for correct use of the inhaler, similar to that provided by the manufacturers with the prescribed medications, and had 30 minutes to practice using the inhaler (without the capsule); they were given no verbal training or demonstration at this time. Patients were then given the blister containing the capsules and asked to demonstrate their use of the inhaler, under the observation of two trained respiratory assessors. This provided an assessment of first use on the basis of written instructions for use only.

The same assessors recorded each patient's ability to perform each of the 21 steps required for correct use of Breezhaler and the 19 steps for HandiHaler, using an assessment checklist for correct use prepared specifically for this study (for details of the checklists, see Table 4, Results).

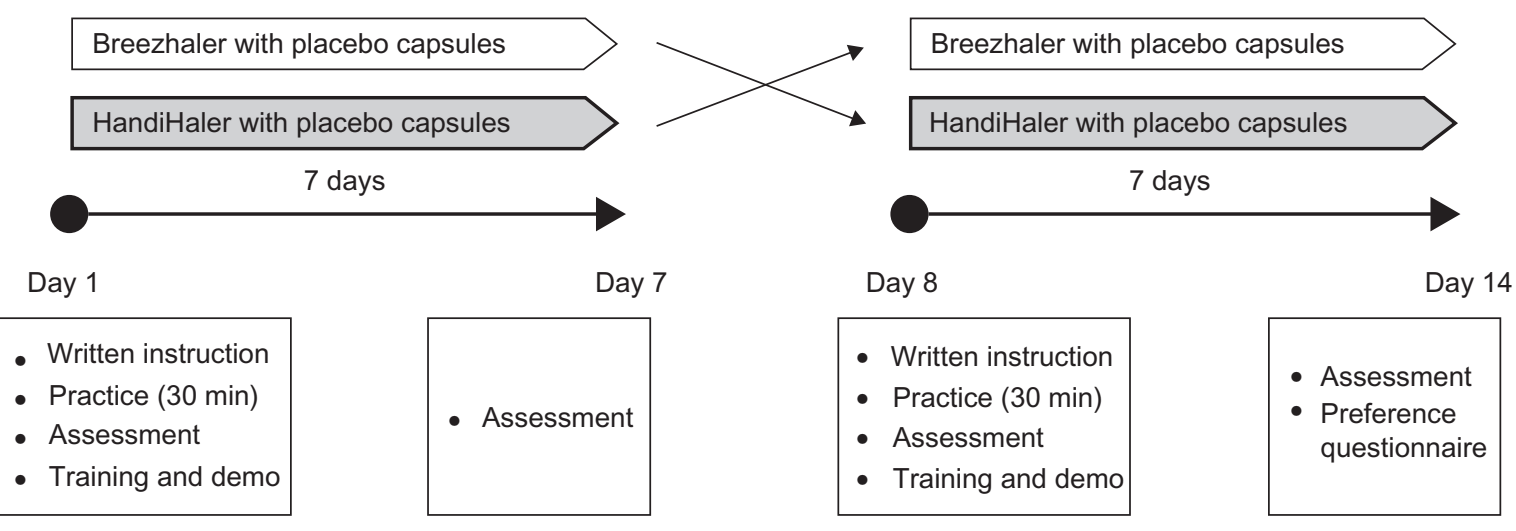

Figure 2 Study design. 
Steps were classed as correct ('yes' or 'fully completed') or incorrect ('no' or 'not fully completed'). For each inhaler, two steps were identified as critical for appropriate dose delivery: full release of the piercing buttons (allowing capsule rotation), and exhalation away from the mouthpiece before inhalation. Study center personnel then trained the patients verbally and demonstrated (without capsules) how to use the inhaler properly before the patients went home. Training was standardized across the study centers. These procedures were repeated at the start of the second study treatment period. At the end of each treatment period (ie, on Day 7 of each period), patients' correct inhaler use and inhalation technique were re-assessed by the same assessors. After the assessment at the end of the second treatmentperiod, patients were given both inhalers used during the study and had a few minutes to re-familiarize themselves with the two inhalers. They were then asked to complete the patient preference questionnaire (for questionnaire details, see Table 5, Results). The handling assessment checklist and preference questionnaire were developed by the study sponsor. In the absence of available validated assessment tools, the handling assessment checklist and preference questionnaire were developed using the patient information leaflets for the inhalers and previously published studies investigating inhaler use, and were not validated.

\section{Objectives and outcomes}

The primary objective of this study was to assess patients' correct use of the two inhalers after 7 days of daily use, ie, under preferable conditions where the patient has read the instructions for use and has received verbal training and demonstration of correct use. Secondary objectives included the assessment of correct use after reading written instructions on Day 1, the performance of the two critical steps on Days 1 and 7, and patients' preference between the inhalers. The comparison of the total handling scores, calculated from the device handling assessment checklists, and each item of the preference questionnaire, were exploratory objectives.

\section{Statistical methods}

Results for each step of the device handling assessment checklist were summarized by inhaler type as number and percentage of patients. A step was classified as correct if the response was either 'yes' or 'fully completed'. If the responses differed between the assessors, the step was classed as incorrect. For each patient, a total handling score was calculated as the number (percentage) of checklist items with correct use out of the total number of items. The total handling scores for the two inhalers were summarized as percentages and compared using a mixed analysis of variance model (Stat Proc Mixed) with fixed effects for period and inhaler and a random effect for patient. The difference in total handling score is presented with $95 \%$ confidence intervals (CIs) and associated $P$-value. Responses to each question in the preference questionnaire were summarized by inhaler type as number and percentage of patients. For questions eliciting a preference between the two inhalers a Mainland-Gart test was performed to allow for period effects, ignoring patients showing no preference. For responses on a 10-point scale, a mixed-model analysis of variance was used as described for the total handling score analysis.

A formal sample size calculation was not performed, because the study was exploratory in nature. The total number of 80 patients was chosen based on previous studies that had included approximately $60-70$ patients. ${ }^{19,20}$

\section{Results}

\section{In-vitro dose delivery study}

A group of 28 inhalation profiles was reviewed and seven patient inhalation profiles were selected to be representative of a COPD population, including moderate and severe stages of COPD, an approximately equal number of males and females, and a range of ages and inhalation variables (Table 1 and Figure 3). The mean FPF was $26.8 \%$ of the $150 \mu \mathrm{g}$ label claim for Breezhaler, while the mean FPF from the HandiHaler was $9.8 \%$ of the label claim $(18 \mu \mathrm{g})$ (Table 2). The two inhalers generated particles of similar uniformity of size, but the mean size of the drug particles from the Breezhaler was smaller than those generated by the HandiHaler (3.2 $\mu \mathrm{m}$ compared with $3.9 \mu \mathrm{m})$.

Mean estimated intrathoracic drug deposition as a percentage of the mean delivered dose (Table 2) was 31\% for the Breezhaler and 22\% for the HandiHaler (Figure 4). Mean estimated extrathoracic drug deposition was 57\% for Breezhaler and $71 \%$ for HandiHaler.

\section{Assessment of patients' correct use of, and preference for, inhalers}

Eighty-three patients with COPD severities ranging from mild to severe were randomized. One patient was randomized in error and left the study before any Day 1 procedures had been carried out. This patient was not included in the analysis population, which comprised 82 patients (Table 3 ). 
Table I Patient demographics and derived inhalation variables through the two inhalers

\begin{tabular}{|c|c|c|c|c|c|c|c|c|c|c|c|c|}
\hline \multirow[t]{2}{*}{$\begin{array}{l}\text { Patient } \\
\text { no. }\end{array}$} & \multirow[t]{2}{*}{ Age (yr) } & \multirow[t]{2}{*}{ Gender } & \multirow[t]{2}{*}{$\begin{array}{l}\text { FEV } \\
\text { (\% pred.) }\end{array}$} & \multirow[t]{2}{*}{ COPD } & \multicolumn{2}{|c|}{$\begin{array}{l}\text { DP } \\
\left(\mathrm{cmH}_{2} \mathrm{O}\right)\end{array}$} & \multicolumn{2}{|c|}{$\begin{array}{l}\text { PIF } \\
\text { (L/minute) }\end{array}$} & \multicolumn{2}{|c|}{ IV (L) } & \multicolumn{2}{|c|}{$\begin{array}{l}\text { IT } \\
\text { (seconds) }\end{array}$} \\
\hline & & & & & $\mathrm{BH}$ & HH & $\mathrm{BH}$ & $\mathbf{H H}$ & $\mathbf{B H}$ & $\mathrm{HH}$ & $\mathbf{B H}$ & $\mathbf{H H}$ \\
\hline 1 & 74 & Male & 69 & Moderate & 24 & 31 & 80 & 34 & 2.2 & 1.9 & 2.5 & 6.3 \\
\hline 2 & 69 & Male & 39 & Severe & 35 & 58 & 97 & 47 & 2.1 & 1.6 & 1.9 & 3.0 \\
\hline 3 & 79 & Male & 58 & Moderate & 8 & 14 & 47 & 23 & 1.3 & 1.5 & 3.0 & 6.1 \\
\hline 4 & 70 & Female & 74 & Moderate & 9 & 15 & 48 & 24 & 1.7 & 1.4 & 3.2 & 5.0 \\
\hline 5 & 52 & Female & 68 & Moderate & 37 & 44 & 99 & $4 I$ & 2.0 & 1.8 & 1.7 & 3.8 \\
\hline 6 & 76 & Female & 66 & Moderate & 15 & 34 & 64 & 36 & 1.0 & 1.3 & 1.3 & 3.1 \\
\hline 7 & 71 & Female & 49 & Severe & 19 & 61 & 72 & 48 & 1.8 & 1.5 & 2.0 & 2.3 \\
\hline Average & 70 & - & 60 & - & 21 & 37 & 72 & 36 & 1.7 & 1.6 & 2.2 & 4.2 \\
\hline
\end{tabular}

Abbreviations: $\mathrm{FEV}$, forced expiratory volume in I s; DP, pressure drop across inhaler; PIF, peak inspiratory flow; IV, inhaled volume; IT, inhalation time; BH, Breezhaler; $\mathrm{HH}$, HandiHaler; yr, years.

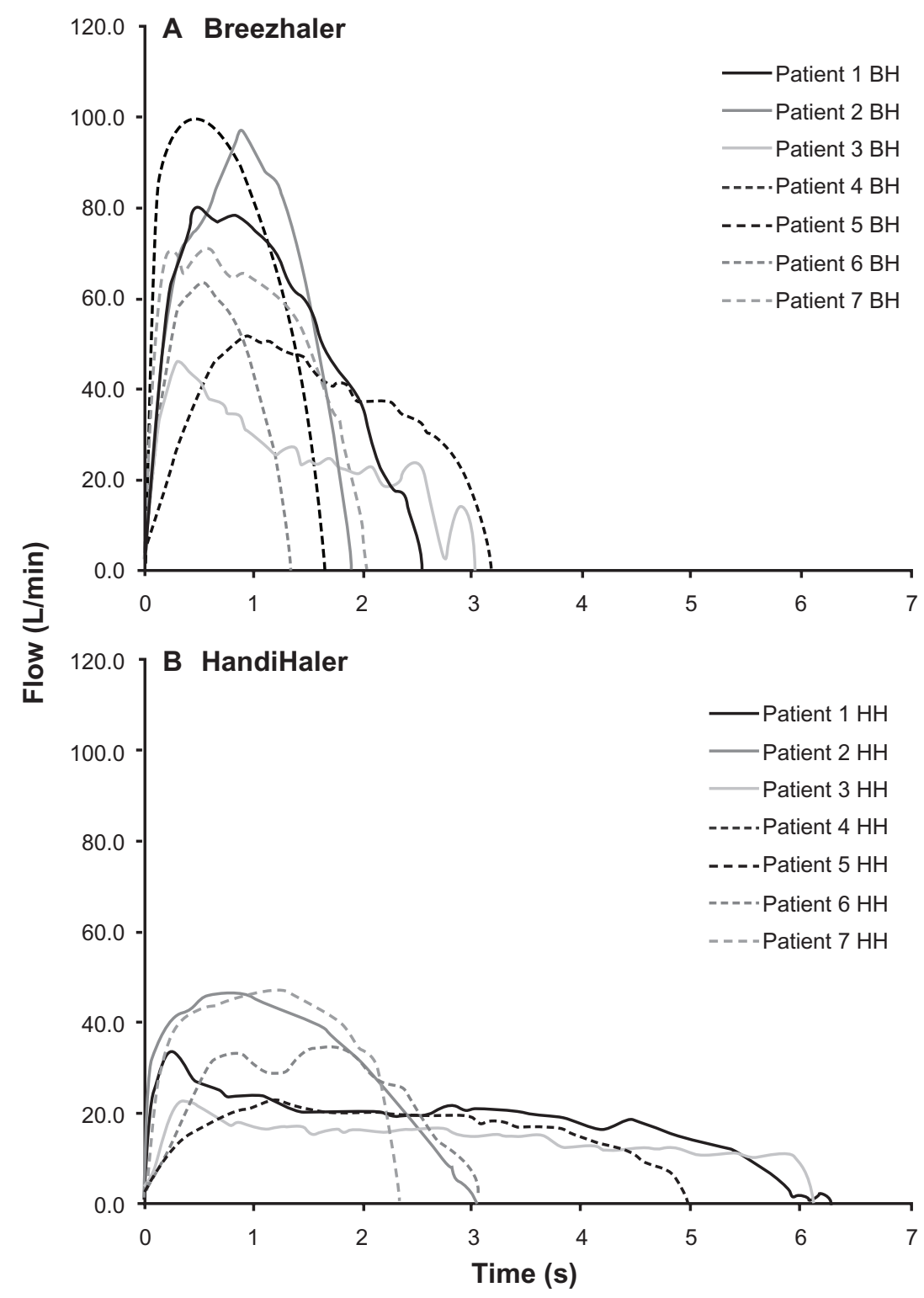

Figure 3 Individual inhalation flow profiles for the selected patients through (A) Breezhaler and (B) HandiHaler.

Abbreviations: $\mathrm{BH}$, Breezhaler; $\mathrm{HH}$, HandiHaler. 
Table 2 Characteristics of aerosols generated using patient inhalation profiles representative of moderate to severe COPD

\begin{tabular}{|c|c|c|c|c|c|c|c|c|c|c|}
\hline \multirow{2}{*}{$\begin{array}{l}\text { Patient } \\
\text { no. }\end{array}$} & \multicolumn{5}{|c|}{ Breezhaler } & \multicolumn{5}{|c|}{ HandiHaler } \\
\hline & $\begin{array}{l}\text { DD } \\
(\mu g)^{a}\end{array}$ & $\begin{array}{l}\text { FPD } \\
(\mu g)^{b}\end{array}$ & $\begin{array}{l}\text { FPF } \\
(\%)^{c}\end{array}$ & $\begin{array}{l}\text { MMAD } \\
(\mu \mathrm{m})^{\mathrm{d}}\end{array}$ & GSD $^{\mathbf{e}}$ & $\begin{array}{l}\text { DD } \\
(\mu g)^{a}\end{array}$ & $\begin{array}{l}\text { FPD } \\
(\mu \mathrm{g})^{\mathrm{b}}\end{array}$ & $\begin{array}{l}\text { FPF } \\
(\%)^{c}\end{array}$ & $\begin{array}{l}\text { MMAD } \\
(\mu \mathrm{m})^{d}\end{array}$ & GSD \\
\hline 1 & 112 & 46.6 & 31.1 & 3.1 & 1.9 & 7.9 & 1.7 & 9.6 & 3.9 & 1.9 \\
\hline 2 & 113 & 47.8 & 31.9 & 3.0 & 1.9 & 8.0 & 1.9 & 10.4 & 3.7 & 1.8 \\
\hline 3 & 83 & 27.1 & 18.0 & 3.5 & 2.0 & 6.7 & 1.4 & 7.6 & 4.4 & 1.8 \\
\hline 4 & 96 & 32.6 & 21.7 & 3.5 & 1.9 & 7.8 & 1.8 & 10.0 & 4.2 & 1.8 \\
\hline 5 & 113 & 47.9 & 31.9 & 2.9 & 1.9 & 6.9 & 1.7 & 9.4 & 3.8 & 1.8 \\
\hline 6 & 87 & 33.4 & 22.3 & 3.2 & 2.0 & 8.2 & 2.0 & 10.9 & 3.8 & 1.8 \\
\hline 7 & 111 & 45.8 & 30.5 & 3.0 & 1.9 & 7.8 & 2.0 & 10.9 & 3.9 & 1.9 \\
\hline Mean (SD) & $\begin{array}{l}102.0 \\
(14.53)\end{array}$ & $\begin{array}{l}40.2 \\
(8.70)\end{array}$ & $\begin{array}{l}26.8 \\
(5.80)\end{array}$ & $\begin{array}{l}3.2 \\
(0.22)\end{array}$ & $\begin{array}{l}2.0 \\
(0.07)\end{array}$ & $\begin{array}{l}7.6 \\
(0.82)\end{array}$ & $\begin{array}{l}1.8 \\
(0.30)\end{array}$ & $\begin{array}{l}9.8 \\
(1.65)\end{array}$ & $\begin{array}{l}3.9 \\
(0.29)\end{array}$ & $\begin{array}{l}1.8 \\
(0.06)\end{array}$ \\
\hline
\end{tabular}

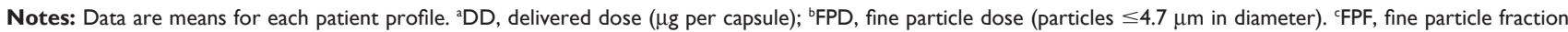
(particles $\leq 4.7 \mu \mathrm{m}$ in diameter) as \% of label claim dose (indacaterol I50 $\mu \mathrm{g}$ via Breezhaler, tiotropium I8 $\mu \mathrm{g}$ via HandiHaler); dMMAD, median mass aerodynamic diameter (ie, the size of drug particles); ${ }^{\mathrm{G}} \mathrm{GSD}$, geometric standard deviation, a measure of the uniformity of particle size.

Abbreviation: SD, standard deviation.

\section{Patients' correct inhaler use}

The results for each checklist item on Days 1 and 7 are shown in Table 4. For most steps, the proportion of patients correctly performing the step increased from Day 1 to Day 7. On Day 7, each step was performed correctly by most patients ( $78 \%-100 \%$ for Breezhaler; $81 \%-100 \%$ for HandiHaler). For the critical step of fully releasing the button before inhalation, the Breezhaler score was similarly high on both days (93\%, 96\%), while for the HandiHaler the proportion of patients correctly completing this step changed by $11 \%$ from $88 \%$ (Day 1) to $99 \%$ (Day 7). The other critical step (breathing out away from the inhaler before inhalation) was completed correctly on Day 7 by $85 \%$ of patients with Breezhaler and $81 \%$ of patients using the HandiHaler. The percentage of patients without a critical error was $81 \%$ and $83 \%$ on Days 1 and 7 , respectively, for Breezhaler, and $70 \%$ and $81 \%$ on Days 1 and 7, respectively, for HandiHaler.

Total handling scores on Day 7 (least squares means) were 93.5\% for Breezhaler and $94.4 \%$ for HandiHaler, a mean difference of -1.0 (95\% CI -3.0 to $1.1 ; P=0.357)$. On Day 1 , scores were $91.8 \%$ for Breezhaler and $90.6 \%$ for HandiHaler, a difference of $1.2(95 \% \mathrm{CI}-1.2$ to $3.6 ; P=0.333)$.

\section{Patients' inhaler preference}

The results of the preference questionnaire are presented in Figures 5 and 6 and Table 5. In response to the overall preference question, more patients chose Breezhaler as their preferred inhaler to use on a daily basis (61\% of patients) compared with HandiHaler $(31 \%)(P=0.010)$. For individual responses, Breezhaler was preferred for ease of opening the

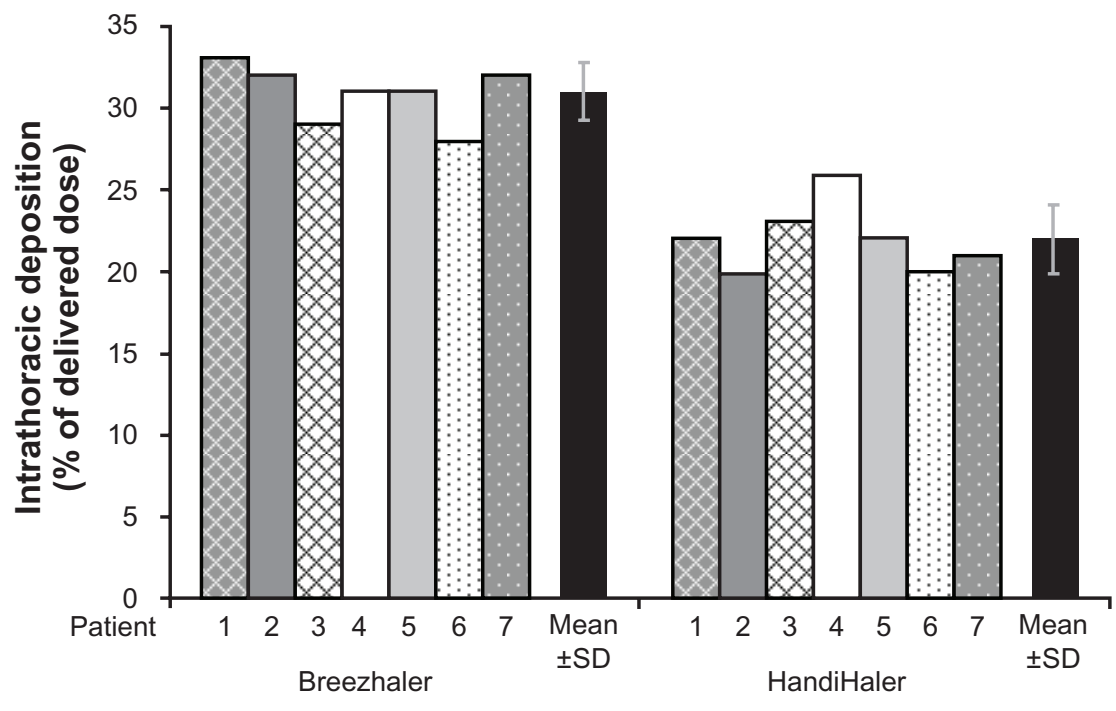

Figure 4 Theoretical intrathoracic drug deposition as a percentage of delivered dose. Abbreviation: SD, standard deviation. 
Table 3 Patients' baseline characteristics $(n=82)$

\begin{tabular}{|c|c|}
\hline Age, years & $63.9(9.21)$ \\
\hline \multicolumn{2}{|l|}{ Age group, n (\%) } \\
\hline $40-64$ years & $40(49)$ \\
\hline$\geq 65$ years & $42(5 I)$ \\
\hline Male/female, \% & $60 / 40$ \\
\hline BMI, $\mathrm{kg} / \mathrm{m}^{2}$ & $29.3(6.29)$ \\
\hline \multicolumn{2}{|l|}{ BMI group, n (\%) } \\
\hline$\leq 30.0 \mathrm{~kg} / \mathrm{m}^{2}$ & $49(60)$ \\
\hline$>30.0 \mathrm{~kg} / \mathrm{m}^{2}$ & $33(40)$ \\
\hline \multicolumn{2}{|l|}{ COPD severity, n (\%) } \\
\hline Mild & $29(35)$ \\
\hline Moderate & $4 I(50)$ \\
\hline Severe & $10(12)$ \\
\hline Ex-smoker/smoker, \% & $50 / 50$ \\
\hline Smoking history, pack-years & $50.4(27.52)$ \\
\hline \multicolumn{2}{|l|}{ Duration of inhaled medication, $\mathrm{n}(\%)$} \\
\hline$<5$ years & $58(7 \mathrm{I})$ \\
\hline $5-9$ years & $13(16)$ \\
\hline $10-14$ years & $5(6)$ \\
\hline$\geq 15$ years & $6(7)$ \\
\hline Post-bronchodilator FEV , L $^{\mathrm{b}}$ & $2.0(0.67)$ \\
\hline Post-bronchodilator $\mathrm{FEV}_{1}, \%$ predicted ${ }^{\mathrm{b}}$ & $73(16.7)$ \\
\hline Post-bronchodilator $\mathrm{FEV}_{\mathrm{l}} / \mathrm{FVC}, \%^{\mathrm{b}}$ & $60(8.6)$ \\
\hline
\end{tabular}

Notes: Data are mean (standard deviation) unless otherwise stated. ${ }^{2} \mathrm{Data}$ missing for two patients whose post-bronchodilator $\mathrm{FEV} / \mathrm{FVC}$ was $>70 \%$; ${ }^{\mathrm{b}} \mathrm{FEV}$, and $\mathrm{FVC}$ were measured 10-15 minutes after inhalation of four puffs of salbutamol $100 \mu \mathrm{g}$ (four puffs of albuterol $90 \mu \mathrm{g}$ ).

Abbreviations: $\mathrm{BMI}$, body mass index; $\mathrm{FEV}_{\text {, }}$, forced expiratory volume in I second; FVC, forced vital capacity.

cap and mouthpiece (both $P<0.001$ ), closing the mouthpiece after inserting the capsule $(P=0.005)$ and holding the inhaler $(P<0.001)$. There were no statistically significant preferences for HandiHaler. The mean scores for the items scored on a 1-10 scale (comfort of inhalation, simplicity of use and confidence in successful intake of medication) were slightly greater with Breezhaler than with HandiHaler, and the differences in mean score were statistically significant (Figure 6).

\section{Discussion}

Breath actuation was a major advantage when DPIs were developed, overcoming problems that patients had in coordinating actuation and inhalation with pressurized metered-dose inhalers. However, breath actuation also meant that patients had to generate an inspiratory effort to overcome the internal resistance of the DPIs. Breezhaler has a lower internal resistance than HandiHaler (specific airflow resistances of 2.2 and $5.1 \times 10^{-2} \mathrm{kPa}^{1 / 2} \mathrm{~L}^{-1}$ minute, respectively). ${ }^{21}$ Thus, the Breezhaler requires less inspiratory effort to achieve a given inspiratory flow or, as reflected in the inspiratory flow profiles, permits a higher inspiratory flow for a given effort. We measured the inhalation patterns of 28 patients, subsequently using the profiles of seven patients as a result of various exclusion criteria, the main one being the $100 \mathrm{~L} /$ minute calibration limit of the measuring equipment. This limited the study to the potentially 'poorer' end of the inspiratory profiles for Breezhaler (as the low resistance permits inspiratory flows higher than the set limit) but not for the HandiHaler, since achievable inhalation flow rates for this higher-resistance inhaler would tend to be well within the calibration limit.

Although certain characteristics are desirable in terms of inhaler design, our in vitro comparisons of particles generated by the two inhalers should not be extrapolated directly to the clinical situation, where therapeutic doses are selected based on demonstrated pharmacodynamic responses. The higher FPF and the lower extrathoracic deposition of drug delivered by the Breezhaler compared with the HandiHaler are examples of such desirable properties. The higher FPF with Breezhaler (27\%) relative to HandiHaler (10\%) suggests that a higher proportion of the dose would be delivered to the smaller airways. A higher extrathoracic deposition (71\% of the dose delivered by HandiHaler compared with 57\% for Breezhaler) would reflect the amount of drug deposited in the mouth and oropharynx and swallowed, giving rise to systemic exposure and a risk of side effects. However, while particle size is determined by the inhaler, the distribution of particles in the lung depends on both particle size and inspiratory flow, ${ }^{22}$ and the bronchodilator effect of the drug particles is a complex function of local drug concentration, receptor and airway smooth muscle distribution and the pathology of the disease. While airway smooth muscle is relatively sparse in the alveolar region, this is where $\beta_{2}$-adrenoceptor density is highest. ${ }^{23} \mathrm{~A} \beta_{2}$-agonist bronchodilator for COPD, this being a disease primarily of the small airways and alveoli, would ideally be delivered as small particles (FPF) and activate receptors in those regions. Muscarinic receptors on airway smooth muscle are located more densely in the lower trachea and bronchi than in the smaller airways. ${ }^{24}$

It was recently shown that patients with a wide range of COPD severity, including very severe, are able to generate adequate inspiratory flows with Breezhaler and that a consistent dose is delivered irrespective of disease severity and age. ${ }^{21}$ COPD patients with more severe airways obstruction have been shown to inhale slower through DPIs (compared with patients with less severe impairment) and may have problems achieving an adequate inspiratory flow through high-resistance DPIs. ${ }^{13,25,26}$ A trend towards increasing patient acceptability with decreasing inhaler resistance has been shown, although the effect plateaued as resistance continued to decrease. ${ }^{19}$

Inhaler resistance, although important, is not the only factor contributing to the acceptability of inhalers to patients. Patients found Breezhaler not only more comfortable to 
Table 4 Percentage of patients correctly completing each item of the checklists on Day I and Day 7

\begin{tabular}{|c|c|c|c|c|c|}
\hline (a) Breezhaler checklist & Day I & Day 7 & (b) HandiHaler checklist & Day I & Day 7 \\
\hline I. Pull off cap & 100.0 & 100.0 & I. Open the cap & 98.8 & 97.5 \\
\hline 2. Open mouthpiece & 98.8 & 100.0 & 2. Open mouthpiece & 96.3 & 97.5 \\
\hline 3. Remove capsule from blister pack & 98.8 & 100.0 & 3. Remove capsule from blister pack & 93.8 & 97.5 \\
\hline 4. Insert capsule in the inhaler & 100.0 & 100.0 & 4. Insert capsule in the inhaler & 98.8 & 100.0 \\
\hline \multirow[t]{2}{*}{ 5. Close inhaler - click heard } & 98.8 & 98.8 & 5. Close inhaler - click heard & 98.8 & 98.8 \\
\hline & & & 6. Was the mouthpiece facing upwards? & 96.3 & 97.5 \\
\hline 6. Pierce the capsule & 95.1 & 98.8 & 7. Pierce the capsule & 97.5 & 96.3 \\
\hline 7. Pierced once only & 92.7 & 91.4 & 8. Pierced once only & 95.1 & 90.0 \\
\hline 8. Click/piercing noise heard by assessor & 92.7 & 100.0 & 9. Click/piercing noise heard & 93.8 & 95.0 \\
\hline 9. Was inhaler held upright? & 89.0 & 88.9 & & & \\
\hline 10. Were both buttons pressed simultaneously? & 95.1 & 97.5 & & & \\
\hline II. Release buttons & 90.2 & 97.5 & 10. Release button & 88.9 & 96.3 \\
\hline $\begin{array}{l}\text { 12. Were buttons fully released before } \\
\text { inhalation? }\end{array}$ & 92.7 & 96.3 & II. Was button fully released before inhalation? & 87.7 & 98.8 \\
\hline \multirow[t]{2}{*}{ 13. Breathe out - not into mouthpiece ${ }^{a}$} & 84.1 & 85.2 & 12. Breathe out - not into mouthpiece ${ }^{\mathrm{a}}$ & 80.2 & 81.3 \\
\hline & & & 13. Was inhaler held horizontally during inhalation? & 85.2 & 95.0 \\
\hline 14. Inhale the medicine rapidly and steadily & 87.8 & 93.8 & 14. Inhale the medicine slowly and deeply & 88.9 & 93.8 \\
\hline 15. Were the air inlets unobstructed by fingers? & 92.7 & 91.4 & I5. Were the air inlets unobstructed by fingers? & 91.4 & 95.0 \\
\hline 16. Audible whirring noise & 82.9 & 91.4 & & & \\
\hline 17. Hold breath for as long as is comfortable & 84.1 & 77.8 & 16. Hold breath for as long as is comfortable & 75.3 & 86.3 \\
\hline $\begin{array}{l}\text { 18. Check upon whether capsule has been fully } \\
\text { emptied }\end{array}$ & 80.5 & 77.8 & & & \\
\hline $\begin{array}{l}\text { 19. If residue is remaining in capsule, did patient } \\
\text { close inhaler and repeat steps } 13-18\end{array}$ & 82.1 & 80.8 & $\begin{array}{l}\text { 17. Did the patient repeat steps } 12-16 \\
\text { to ensure full dose was taken from capsule? }\end{array}$ & 69.1 & 83.8 \\
\hline $\begin{array}{l}\text { 20. Open inhaler, remove capsule, close inhaler } \\
\text { and replace cap }\end{array}$ & 95.1 & 96.3 & 18. Open cap, remove capsule, close and replace cap & 88.9 & 97.5 \\
\hline 21. Was capsule pierced at both ends? & 93.9 & 98.8 & 19. Was capsule pierced at both ends? & 95.1 & 96.3 \\
\hline
\end{tabular}

Note: aPrespecified as a particularly critical step.

inhale through but also simpler to use, and they were more confident that the medication had been taken correctly. Significant differences in scores also favored Breezhaler over the HandiHaler for removing the cap and for opening and closing the mouthpiece. These initial impressions, after a relatively short familiarization period, may be very important to ensure adherence and continued use, which are poor with COPD patients. ${ }^{9,27}$ It seems intuitive that a patient is more likely to use an inhaler that they like and find easy to use, although studies in asthma patients have failed to show an association between inhaler preference and adherence. ${ }^{28,29}$ However, physical difficulty in handling medication has been identified as a significant predictor of low adherence. ${ }^{30}$

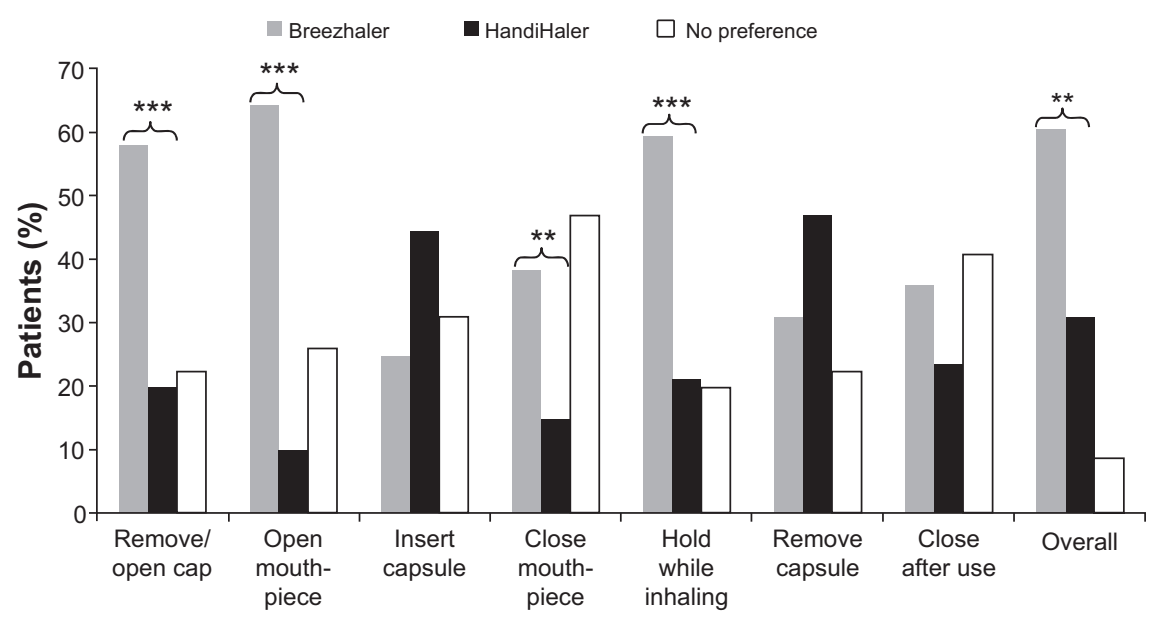

Figure 5 Patient preference for the two inhalers with respect to the different steps in use. Notes: $* * P \leq 0.01$; $* * * P<0.00$ I between the two inhalers. 


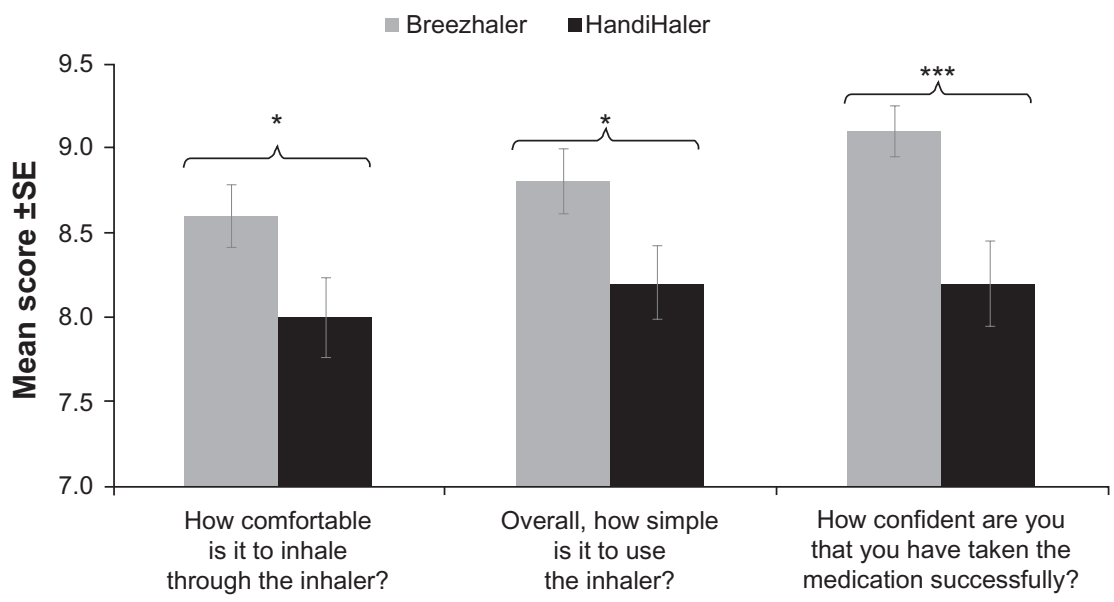

Figure 6 Patient preference for the two inhalers with respect to overall comfort, simplicity and confidence in use.

Notes: $* P<0.05 ; * * * P \leq 0.00$ I between the two inhalers. (Preference measured on a 10 -point scale from I to 10 .)

Abbreviation: SE, standard error.

With the two inhalers evaluated in this study, the proportion of patients completing each step correctly generally increased over the 7 days, reflecting the effects of training and familiarization. For the critical step of releasing the button(s) prior to inhalation, scores were reasonably high on both days with Breezhaler (93\% on Day 1 and $96 \%$ on Day 2), but were relatively poor (88\%) on Day 1 with HandiHaler, increasing 11 percentage points by Day 7 . With many inhalers, written instructions alone may be inadequate for successful use and training and familiarization through daily use are required before correct use can be achieved. This was also demonstrated by differences of $9 \%-11 \%$ in the

Table 5 Patient preference questionnaire results

\begin{tabular}{|c|c|c|c|c|}
\hline & Breezhaler & HandiHaler & No preference & $P$-value \\
\hline \multicolumn{5}{|l|}{ 1) Questions about the ease and comfort of using the inhalers } \\
\hline (a) Which is easier to remove/open the cap of the inhaler? & 58.0 & 19.8 & 22.2 & $<0.00$ I \\
\hline (b) Which mouthpiece is easier to open? & 64.2 & 9.9 & 25.9 & $<0.001$ \\
\hline (c) Which is easier to insert the capsule in the inhaler? & 24.7 & 44.4 & 30.9 & 0.059 \\
\hline (d) Which is easier to close (after inserting the capsule)? & 38.3 & 14.8 & 46.9 & 0.005 \\
\hline (e) How comfortable is it to inhale medication through the inhaler? & & & & 0.031 \\
\hline Mean (SD) & $8.6(1.67)$ & $8.0(2.10)$ & & \\
\hline Median (range) & $9.0(1.0-10.0)$ & $9.0(1.0-10.0)$ & & \\
\hline (f) Which is easier to hold while inhaling the medication? & 59.3 & 21.0 & 19.8 & $<0.001$ \\
\hline (g) Which is easier for removing the empty capsule? & 30.9 & 46.9 & 22.2 & 0.136 \\
\hline (h) Which is easier to close after use? & 35.8 & 23.5 & 40.7 & 0.244 \\
\hline (i) Overall, how simple is it to use the inhaler? & & & & 0.046 \\
\hline Mean (SD) & $8.8(1.80)$ & $8.2(1.96)$ & & \\
\hline Median (range) & $9.0(1.0-10.0)$ & $9.0(1.0-10.0)$ & & \\
\hline
\end{tabular}

(a)/(b) Do you use a specific check to ensure you have inhaled the medication? ${ }^{b}$

Any specific check

Listen to vibration/whirring

Other check

(c) How confident are you that you have taken the medication successfully?

Mean (SD)

Median (range)

3) Question about overall preference

Which of the inhalers would you prefer to use on a daily basis?

$\begin{array}{ll}90.1 & 81.5 \\ 84.0 & 71.6 \\ 58.0 & 33.3\end{array}$

$\begin{array}{ll}9.1(1.37) & 8.2(2.29) \\ 10.0(4.0-10.0) & 9.0(1.0-10.0)\end{array}$

60.5
0.001

8.6

0.010

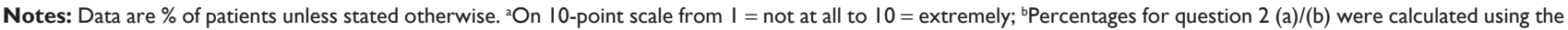
full analysis set (Breezhaler, $\mathrm{n}=82$; HandiHaler, $\mathrm{n}=81$ ); ' For comparison between inhalers; ${ }^{\circledR}$ Not tested, because item did not relate to a preference. 
proportion correctly completing other steps with HandiHaler (holding inhaler horizontally, breath holding, and the capsuleremoval procedure). Because Day 1 scores were generally higher with Breezhaler, the differences between Day 1 and Day 7 scores were generally smaller. For the other critical step, about $15 \%$ of patients using the Breezhaler and $20 \%$ using the HandiHaler failed to breathe out away from the inhaler before inhalation on both Days 1 and 7 .

These data highlight areas for focusing educational efforts. Continued education and monitoring of inhaler use improve adherence and are critical factors to successful management, and may well have equal or greater importance than inhaler type. ${ }^{1}$ It is known that initial appropriate use is lost over time, ${ }^{19}$ and continued evaluation of correct inhaler use by treating physicians is especially important among older patients and those receiving multiple medications., ${ }^{9,30,31}$

In conclusion, most patients used both inhalers correctly after 7 days. Patients preferred the Breezhaler overall and scored it more highly than the HandiHaler for the majority of questions in the preference questionnaire. Breezhaler is a low-resistance inhaler suitable for use by patients with a range of disease severities. These are important factors for ensuring optimum dose delivery, patient adherence with treatment and successful COPD management.

\section{Acknowledgments}

The authors thank the patients and staff participating in the study. The authors also thank Inamed Research $\mathrm{GmbH}$ and Co. KG, Gauting, Germany who carried out the in vitro dose delivery study and analyzed the results.

The studies were sponsored by Novartis Pharma AG, represented by the authors $\mathrm{CP}, \mathrm{CL}, \mathrm{DJ}, \mathrm{JD}, \mathrm{MD}$ and $\mathrm{BK}$, who substantially contributed to the conception and design of the study. KRC, CMF, CL, DJ, JD, MD and BK were responsible for acquisition of data, $\mathrm{CP}$ was responsible for analysis of data, and all authors were involved in the interpretation of the data. All authors revised the article critically for important intellectual content, and gave their final approval of the version to be published. KRC had full access to the data and vouches for the integrity of the data and the accuracy of the data analysis.

Sarah Filcek (ACUMED), a professional medical writer funded by Novartis, and David Young (Novartis) assisted in the preparation of the manuscript.

\section{Conflict of interest statement}

KRC: In the past 3 years, Dr Chapman has received compensation for consulting with Astra Zeneca, Boehringer-Ingelheim,
CSL Behring, Glaxo Smith Kline, Merck Frosst, Novartis, Nycomed, Pfizer, Roche, Schering Plough and Telacris; has undertaken research funded by AstraZeneca, BoehringerIngelheim, CSL Behring, Forest Labs, Glaxo Smith Kline, Novartis, Parangenix, Roche and Talecris; and has participated in continuing medical education activities sponsored in whole or in part by Astra Zeneca, Boehringer-Ingelheim, Glaxo Smith Kline, Grifols, Merck Frosst, Novartis, Nycomed, Pfizer and Talecris.

CMF: In the past 3 years, Dr. Fogarty has undertaken research funded by Altana, Amgen, BioMark Pharmaceuticals, Boehringer-Ingelheim, Dey Labs, Forest Labs, Genzyme, Glaxo Smith Kline, Merck, Osiris Therapeutics, Novartis, Novo Nordisk, Pearl Therapeutics, Perrigo, Roche, SanofiAventis, and Takeda. He has not received any compensation for consulting or CME activities in the past 3 years.

CP, CL, DJ, JD, MD and BK are employees of Novartis.

\section{References}

1. Dolovich MB, Ahrens RC, Hess DR, et al. Device selection and outcomes of aerosol therapy: evidence-based guidelines: American College of Chest Physicians/American College of Asthma, Allergy, and Immunology. Chest. 2005;127(1):335-371.

2. Hesselink AE, Penninx BW, Wijnhoven HA, Kriegsman DM, van Eijk JT. Determinants of an incorrect inhalation technique in patients with asthma or COPD. Scand J Prim Health Care. 2001;19(4): 255-260.

3. Vincken W, Dekhuijzen PR, Barnes P; ADMIT Group. The ADMIT series - Issues in inhalation therapy. 4) How to choose inhaler devices for the treatment of COPD. Prim Care Respir J. 2010;19(1):10-20.

4. Fromer L, Goodwin E, Walsh J. Customizing inhaled therapy to meet the needs of COPD patients. Postgrad Med. 2010;122(2):83-93.

5. Melani AS, Zanchetta D, Barbato N, et al. Inhalation technique and variables associated with misuse of conventional metered-dose inhalers and newer dry powder inhalers in experienced adults. Ann Allergy Asthma Immunol. 2004;93(5):439-446.

6. Wieshammer S, Dreyhaupt J. Dry powder inhalers: which factors determine the frequency of handling errors? Respiration. 2008; 75(1):18-25.

7. Newman SP. Inhaler treatment options in COPD. Eur Respir Rev. 2005; 14(96):102-108.

8. Lavorini F, Magnan A, Dubus JC, et al. Effect of incorrect use of dry powder inhalers on management of patients with asthma and COPD. Respir Med. 2008;102(4):593-604.

9. Restrepo RD, Alvarez MT, Wittnebel LD, et al. Medication adherence issues in patients treated for COPD. Int J Chron Obstruct Pulmon Dis. 2008;3(3):371-384.

10. Dolovich M. New propellant-free technologies under investigation. J Aerosol Med. 1999;12 Suppl 1:S9-S17.

11. Labiris NR, Dolovich MB. Pulmonary drug delivery. Part II: the role of inhalant delivery devices and drug formulation in the therapeutic effectiveness of aerolized medications. Br J Clin Pharmacol. 2003; 56(6):600-612.

12. Janssens W, Vanden Brande P, Hardeman E, et al. Inspiratory flow rates at different levels of resistance in elderly COPD patients. Eur Respir J. 2008;31(1):78-83

13. Al-Showair RA, Tarsin WY, Assi KH, Pearson SB, Chrystyn H. Can all patients with COPD use the correct inhalation flow with all inhalers and does training help? Respir Med. 2007;101(11):2395-2401. 
14. Global initiative for chronic obstructive lung disease (GOLD). Updated 2009. At: http://www.goldcopd.com/. Accessed August 19, 2010.

15. Cazzola M, Matera MG, Lötvall J. Ultra long-acting beta 2-agonists in development for asthma and chronic obstructive pulmonary disease. Expert Opin Investig Drugs. 2005;14(7):775-783.

16. Labiris NR, Dolovich MB. Pulmonary drug delivery. Part I: physiological factors affecting therapeutic effectiveness of aerosolized medications. Br J Clin Pharmacol. 2003;56(6):588-599.

17. ICRP. ICRP Publication 66: Human respiratory tract model for radiological protection. A report of a task group of the International Commission on Radiological Protection. Ann ICRP. 1994;24(1-3): $1-482$.

18. Global initiative for chronic obstructive lung disease (GOLD). Updated 2008. At: http://www.goldcopd.com/. Accessed August 19, 2010.

19. Van der Palen J, Eijsvogel MM, Kuipers BF, Schipper M, Vermue NA. Comparison of the Diskus ${ }^{\circledR}$ Inhaler and the Handihaler ${ }^{\circledR}$ regarding preference and ease of use. J Aerosol Med. 2007;20(1):38-44.

20. Schulte M, Osseiran K, Betz R, et al. Handling of and preferences for available dry powder inhaler systems by patients with asthma and COPD. J Aerosol Med Pulm Drug Deliv. 2008;21(4):321-328.

21. Pavkov R, Mueller S, Fiebich K, et al. Characteristics of a new capsule based dry powder inhaler for the effective delivery of indacaterol. Curr Med Res Opin. 2010;26(11):2527-2533.

22. Usmani OS, Biddiscombe MF, Barnes PJ. Regional lung deposition and bronchodilator response as a function of beta2-agonist particle size. $\mathrm{Am}$ J Respir Crit Care Med. 2005;172(12):1497-1504.
23. Barnes PJ, Basbaum CB, Nadel JA, Roberts JM. Localization of beta-adrenoreceptors in mammalian lung by light microscopic autoradiography. Nature. 1982;299(5882):444-447.

24. Fryer AD, Jacoby DB. Muscarinic receptors and control of airway smooth muscle. Am J Respir Crit Care Med. 1998;158(5 Pt 3): S154-S160.

25. Clark AR. Medical aerosol inhalers: past, present and future. Aerosol Sci Technol. 1995;22(4):374-391.

26. Newman SP, Busse WW. Evolution of dry powder inhaler design, formulation, and performance. Respir Med. 2002;96(5):293-304.

27. Breekveldt-Postma NS, Koerselman J, Erkens JA, Lammers JW, Herings RM. Enhanced persistence with tiotropium compared with other respiratory drugs in COPD. Respir Med. 2007;101(7):1398-1405.

28. Van Schayck CP, Bijl-Hofland ID, Folgering H, et al. Influence of two different inhalation devices on therapy compliance in asthmatic patients. Scand J Prim Health Care. 2002;20(2):126-128.

29. Jäger L, Laurikainen K, Leinonen M, Silvasti M. Beclomethasone dipropionate Easyhaler is as effective as budesonide Turbohaler in the control of asthma and is preferred by patients. Int J Clin Pract. 2000; 54(6):368-372.

30. George J, Kong DC, Thoman R, Stewart K. Factors associated with medication nonadherence in patients with COPD. Chest. 2005;128(5): 3198-3204.

31. Takemura M, Mitsui K, Itotani R, et al. Relationships between repeated instruction on inhalation therapy, medication adherence, and health status in chronicobstructive pulmonary disease. Int J Chron Obstruct Pulmon Dis. 2011;6:97-104.
International Journal of COPD

\section{Publish your work in this journal}

The International Journal of COPD is an international, peer-reviewed journal of therapeutics and pharmacology focusing on concise rapid reporting of clinical studies and reviews in COPD. Special focus is given to the pathophysiological processes underlying the disease, intervention programs, patient focused education, and self management protocols.

\section{Dovepress}

This journal is indexed on PubMed Central, MedLine and CAS. The manuscript management system is completely online and includes a very quick and fair peer-review system, which is all easy to use. Visit http://www.dovepress.com/testimonials.php to read real quotes from published authors. 